\title{
The Subtleties of Social Exclusion: Race, Social Class, and the Exclusion of Blacks in a Racially Mixed Neighborhood
}

\author{
Daniel Monroe Sullivan, Jonathan Picarsic \\ Department of Sociology, Portland State University, Portland, USA \\ Email: dsulliva@pdx.edu
}

Received January $9^{\text {th }}, 2012$; revised February $13^{\text {th }}, 2012$; accepted March $12^{\text {th }}, 2012$

\begin{abstract}
We use interviews, content analysis, and surveys to describe how a neighborhood association in a racially mixed neighborhood in Portland, Oregon (USA) subtly excludes many blacks from being full members of the neighborhood. In contrast to explicit cases of social exclusion, this neighborhood association excludes blacks without ever referring to race. They instead justify their actions-e.g., helping close down a black social club and discouraging more affordable housing-based on such nonracial goals as increasing homeownership, minimizing crime, and maximizing "economic diversity". We argue that without the inclusion of black residents and their neighborhood organizations (e.g., churches) in the decision-making process, mixed-race neighborhoods will continue to lose their diversity.
\end{abstract}

Keywords: Social Inclusion; Neighborhoods; Race; Social Class; Gentrification

\section{Introduction}

There are many cases of minority groups being socially excluded, based on such characteristics as race, ethnicity, caste, gender, or sexual orientation (DFID, 2005; Freiler, 2001; Islam \& Sharmin, 2011), resulting in a lack of equal access to political, social, and economic resources. Many of these cases are explicit, with the exclusion codified in law or deep cultural practices. And there have been attempts at all levels of government and civil society to counteract these by promoting social inclusion (Edwards, 1999; Kay, 2005; Vargas, 2001). This study adds to the development literature by examining a case in which social exclusion based on race is subtle (see Curry et al., 2011 for another example), as those with power in a neighborhood association justify their actions based on wanting to increase the "livability" and social class composition of their neighborhood. Though they never mention race, they engage in activities that disproportionately exclude black residents.

\section{Neighborhood Associations in the United States}

Rising neo-liberalism in the US, like in many countries-e.g., the UK (Powell, 2011) - has led to a decline in direct state intervention and a rise in the importance of civic institutions like NGOs (e.g., Islam \& Sharmin, 2011). Although these civic organizations may still receive financial support from the state, they are largely left to themselves to define and solve their local problems. In the US neighborhood associations have been involved in such activities as encouraging or discouraging certain types of local businesses (Maly, 2005), promoting or discouraging affordable housing (Hartigan, 1999; Kasinitz, 1988), and reducing crime by establishing watch groups and communicating with the police (Pattillo, 2007).

The need for effective neighborhood associations is acute in racially mixed neighborhoods because of historic institutional discrimination against minorities, especially blacks, and the resulting racial tension, mistrust, and economic, political and social inequities (Massey \& Denton, 1993). Neighborhood as- sociations are especially important in neighborhoods that are gentrifying, which is the process by which wealthier residents move into poorer neighborhoods in sufficient numbers to change its social class composition and neighborhood identity. Gentrifying neighborhoods are characterized by imbalances among residents in terms of political, economic, and social resources that can exacerbate inequities (Kasinitz, 1988; Martin, 2007; Smith, 1996). Effective neighborhood associations are even more pertinent these days as there has been in US cities a decline in racial segregation and an increase in racially integrated neighborhoods (Friedman, 2005).

\section{The Promise of Neighborhood Associations}

There are several ways in which neighborhood associations can promote social inclusion. First, they can advocate for the housing needs of longtime, low-income, and minority residents (Nyden, Maly, and Lukehart, 1997), which include affordable rental units, public housing, and institutional housing linked to special needs (e.g., homeless shelters or drug-alcohol treatment centers). Anderson (1990), for example, illustrates how a predominantly white neighborhood association promotes diversity by buying, renovating, and then selling or renting affordable housing to blacks. Brown-Saracino (2004) documents how white residents in a racially diverse gentrifying neighborhood organize to advocate for affordable housing and against luxury condominiums. Robinson (1995) illustrates how residents in a poor black neighborhood bordering a tourist district, organize with help from local affordable housing specialists and city government, to fight for affordable single-resident occupancy housing and against luxury hotels.

Second, neighborhood associations can enhance social integration by supporting businesses and social service agencies that serve the needs of poor and minority residents, promoting multicultural events, and fostering welcoming public spaces (Nyden, Maly, and Lukehart, 1997; Saltman, 1991). They can organize inter-racial picnics, parties, and parades (Anderson, 
1990), promote cultural activities that express pride about living in a diverse neighborhood (Brown-Saracino, 2004), and patronize longtime businesses and discourage the opening of chain stores (Brown-Saracino, 2004).

Third, neighborhood associations can promote diversity as an integral part of their neighborhood's identity (Maly, 2005; Nyden, Maly, \& Lukehart, 1997). They can encourage the media to write positive articles about the neighborhood (Kasinitz, 1988) and even engage in direct marketing and promotional efforts (Saltman, 1991).

\section{The Upshaw Neighborhood in Portland, Oregon (USA) ${ }^{1}$}

If any neighborhood association were predicted to promote social inclusion among black and white residents, the Upshaw Neighborhood Association (UNA) in Portland, Oregon would be a strong candidate. First, the city of Portland has a strong system of neighborhood associations, as they are given resources by the city government and are formally organized under the city government's Office of Neighborhood Involvement (Berry et al., 1993). Portland's neighborhood associations are oftentimes effective in creating changes within their neighborhoods. In terms of fostering racial inclusion, Portland would seem to be a good candidate. In comparison to most US cities, it is less racially segregated and has a larger percentage of white residents and a smaller percentage of black residents (Renn, 2009). Scholars argue that this racial composition would lead to white residents feeling less "racial threat," meaning that they would be less likely to be concerned about living in the same neighborhood as blacks than would white residents living in cities with more segregation and a higher percentage of black residents (Meyers, 1990).

In terms of the Upshaw neighborhood in particular, it would seem to be prime candidate for racial inclusion since historically it has had a significant amount of both black and white residents. In addition, this neighborhood has a substantial number of longtime social institutions like churches and social service agencies, many of which support minorities. Finally, Florida (2002) and other "creative city” advocates (e.g., Bullick et al., 2003) claim that Portland attracts many residents who are “creative," "bohemian," and are attracted to "diversity," which describes many white Upshaw residents particularly well.

\section{Data and Methods}

One of the authors conducted interviews with ten UNA board members, nine members of other neighborhood institutions such as churches and social service agencies, and eight longtime residents who have not participated in UNA recently. Interviewees were recruited using snowball sampling. One of the authors attended general and land use UNA meetings for one year and examined their bylaws, minutes, and newsletters for six years. We include data from a neighborhood survey conducted by one of the authors. Sixty-three percent of randomly selected housing units resulted in 217 completed surveys. Participants were asked, among other questions, to describe their involvement (if any) with UNA.

\section{Social Inclusion... At First Glance}

There are a number of reasons to think that UNA is socially

${ }^{1}$ Names of the neighborhood, organizations, and individuals have been changed to protect privacy. inclusive of black residents. First, its stated mission is to represent all residents, businesses, and organizations, whether or not they participate in UNA. In addition, UNA advocates for vague but seemingly inclusive goals such as securing adequate housing, creating employment opportunities, and improving the quality of urban life. Second, all ten UNA board members who were interviewed mention the importance of social inclusion, often using the word "diversity." They state that Upshaw is currently racially diverse and they want it to remain that way. Joe, a white homeowner and longtime UNA member, says that "I kind of prefer to have my children grow up in an area where there are actually black people and Mexican people and people from Asia and so on.” Naomi, a white homeowner, states, "You have to realize this is a racially mixed neighborhood. There's people from all over here; you've got every flavor of person that you could imagine... I happen to love that; I just think it's fun.” Finally, writers for UNA's newsletter also discuss the importance of social inclusion and "diversity." They wrote 17 articles during a six-year period celebrating "economic diversity," "cultural diversity," "cultural heritage,” and "ethnic diversity.” They also wrote a number of articles highlighting longtime black residents and businesses and they sponsor several multi-cultural events at a local park.

\section{Social Exclusion... Upon Deeper Examination}

UNA, despite what initially looks like an organization that embraces social inclusion, engages in practices that exclude some black residents. What makes their brand of social exclusion subtle is that they justify their actions using non-racial language; they advocate for increasing homeownership, attracting middle-class residents, reducing social service institutions, and enhancing "livability."

\section{Lack of Racial Representation on the UNA Board of Directors and Participants}

Upshaw is a racially diverse neighborhood: about half of its residents are white, non-Hispanic, about a third are black, and about one-fifth are Hispanic, another race, or multi-racial. UNA board members, in contrast, are overwhelmingly white. Eighty percent of the twenty members of the board or land use committee are white; one is black, one is Hispanic, and two are multi-ethnic. A random sample of 217 residents indicates that, of those who attended one or more UNA meetings during a twelve-month period, $87 \%$ were white, while only $13 \%$ were non-white.

Upshaw is also diverse in terms of social class. About a third of its residents has a college degree and owns their house. Those involved in UNA, however, are much more likely to have a college degree and own their home. Of the ten UNA members interviewed, $70 \%$ have a college degree and $89 \%$ own their home; of those attending UNA meetings, $76 \%$ have a college degree and 83\% own their home.

Since many of the UNA participants are white and college educated, we should not be surprised by their overrepresentation. That is because scholars have found that white, college-educated residents tend to be "organizationally dependent": they participate more in formal neighborhood organizations and less in informal interactions (Crenshaw \& St. John, 1989). They are effective operating in formal organizations due to their disposition (e.g., a sense of agency and entitlement), skills, and 
resources (human, financial, social, and cultural capital). They possess, for example, the skills, comfort level, and trust to deal effectively with the city government, police, and other formal institutions. Those who are less educated and poorer, especially racial minorities, often feel less comfortable, competent, and trusting of formal institutions. They may also not have the right kind of cultural capital-e.g., speech patterns, dress style, and other cues that symbolize belonging to the middle class- to fit in (Schneider, 2006). This unequal distribution of skills and comfort level helps explain why Saltman (1991) finds neighborhood associations in 15 racially diverse neighborhoods throughout the US having limited participation from poor and minority residents.

The overrepresentation of white professionals in neighborhood associations is important because most are homeowners, so they focus on raising property values [e.g., promoting retail and historic preservation (Brown-Saracino, 2004; Hartigan, 1999; Kasinitz, 1988) and removing graffiti and other signs of disorder (Maly, 2005; Pattillo, 2007)]. In contrast, nonprofessionals, especially minorities, tend to emphasize informal social relations. St. John \& Clark (1984) find that black and lowerclass residents place more importance on social cohesion and neighborhood services; Lee and Campbell (1997) find that blacks, the unemployed, and longtime residents are more likely to invoke a social definition of a neighborhood.

Second, in cases like ours where the white professionals are gentrifiers researchers have found that they (and their neighborhood associations) - although tolerant of middle-class minorities (Berrey, 2005; Reed, 1999)—are less tolerant of poor residents (Pattillo, 2007), especially minorities living in lowincome housing (Kasinitz, 1988: Robinson, 1995) or institutional housing (Hartigan, 1999; Maly, 2005).

\section{Social Exclusion from Neighborhood Organizations That Serve Black Residents}

A number of other neighborhood organizations serve disadvantaged residents, many of whom are black; UNA could promote social inclusion indirectly by supporting these organizations. Managers and workers at six of these organizations, however, make it clear that UNA is what Meyer and Hyde (2004) call "insular"; UNA does not support them and they have limited contact. Only one of the six organizations currently has any contact with UNA, and that is only to obtain a permit for an annual park event. Of the eight people interviewed from the six organizations, none attend UNA meetings and few read their newsletter.

Three organizations that assist the poor and minorities express negative feelings towards UNA. An administrator at the Manna House, which provides food and clothing to those in need, feels that UNA should be more supportive of their organization:

I would like to see... people in the community connect with agencies like Manna House or All Saints (another neighborhood organization)... Just kind of embrace it and see how they can assist. Because we're feeding someone... that means they're not out robbing. So you need people to look at the big picture.

So, to raise the profile of her organization, she approached UNA about running a story about her organization in their newsletter. They denied her request, telling her that "Oh yeah, you have a good story, but everybody has a story."

An administrator at All Saints, which provides support ser- vices to the neighborhood poor, is also critical of UNA. He feels that UNA should care about needy residents:

$[W]$ e feed (a lot of) people... through this organization. If anybody should have cared about what's going on, (UNA) should have cared about what we're doing, to enhance our ability to meet the needs of those who are less fortunate. So, why did they not pursue us? Why are they not enabling us? Why are they not helping us meet our mission when, in fact, we are taking care of the things that most people like to pretend don't exist?

An employee of a business that assists black businesses and homeowners claims that most black residents are not even aware of the existence of UNA. And even if blacks did participate, they would not have any influence because they do not have money. Another employee at the same business argues that UNA is run by white newcomers who are only concerned about advancing their own interests:

$[P]$ eople move into this community... and the next day they're the neighborhood association, so they're trying to tell you... how this neighborhood should be run. And that's a problem... They're all...against this and that, and none of them had grown up in this neighborhood... Do they really care about the neighborhood?

Not all neighborhood organizations interviewed dislike UNA. One of the six organizations, a predominantly black church that offers social services to the needy, has little contact with, and no opinion of, UNA. The administrator interviewed used to read their newsletter but nothing "caught his attention". An administrator at another local church that assists the needy said that his church has no contact with UNA. He reads their newsletter, however, and feels that they are doing "great things". Finally, two workers at a community center have participated in UNA in the past and they hold positive opinions of that organization.

Given the social exclusion within UNA, and between UNA and neighborhood organizations that support blacks, it is not surprising that their actions in the neighborhood exclude black residents and ultimately take actions that hurt them. Below are two examples that illustrate this dynamic: UNA limiting lowincome and institutional housing and helping close down a black social club.

\section{Limiting Low-Income and Institutional Housing}

Many low-income and minority residents do not own their own home; rather, they reside in apartments, public housing, or institutional housing that assists people in need. UNA discourages more of these types of housing. It adopted a policy, in fact, to oppose more subsidized housing for households earning less than $50 \%$ of the median income. Many UNA members are concerned that these residents commit crimes, consume drugs and alcohol, and increase neighborhood instability. An UNA board member wrote an article in its newsletter advocating for "economic diversity". Like the developers in Berrey’s (2005) study, he states that "low and very low income units" and institutions such as "social service organizations, government agencies for the dysfunctional, and new churches" are preventing the neighborhood from achieving economic diversity. Apparently their presence also damages the neighborhood's reputation. He argues that there are only a few needy residents but the "dumping" of institutions that serve the needy are "perpetuating the image of Upshaw as perpetually depressed”. He advocates 
for other neighborhoods taking more of these institutions so that "as the growing economy changes our neighborhood... (UNA policies) shape future development in a balanced way that ensures diversity across the spectrum of issues". Although the author does not mention race, many of the clients of these institutions are black and the majority of neighborhood churches have predominantly black members.

Other UNA board members agree that the amount of social service agencies and low-income apartments damage the neighborhood's quality of life, but they completely avoid the topic of race. As William says:

It is not a very charitable view, but I think that there are too many social service agency, nonprofit types in the neighborhood. It tends to create this overarching sort of, this "hospital ward" feel.

Joe expresses similar views:

[T] he low-income housing is kind of a destabilizing element. There's a lot of people who are transients. They're in that housing because they don't have a lot of money and eventually they get kicked out of the places. So, new people move in. A lot of them have crummy friends that deal drugs and stuff like that, and those are detrimental...

However, a few board members do not view renters, including those in low-income and institutional housing, as the main source of neighborhood instability. They blame, instead, white, middle-class gentrifiers who are looking to make a profit from their short stay in the neighborhood. Anne, a longtime board member, states:

Remember, the aim behind the neighborhood association was to bring up the level of income in the neighborhood. Their feeling was...that there were too many low-income people in the neighborhood, and... they wanted more affluent people... (so) that it would be technically more stable. But I'm not too sure that's true... A lot of the newer people... stay here a year or two years or three, and they sell... So I don't know how much stabilizing that has done because a lot of these houses that have been here for a long time... they rented for thirty years... They didn't have money to buy, and the people they rented from didn't want to sell. The landlord was good; the tenant was good. The tenant would paper the house, paint the house, and do all those things because they planned on staying there until they died.

Doris also attributes instability to gentrifiers, arguing that they shape the neighborhood to their liking and then leave:

There are white people that move here and spend a certain amount of time and mold the neighborhood in their own image and move out. I have spoken out against that a number of times and got in all kinds of trouble. There is a pattern. People will move here and fix up a house. When their kids get old enough to go to school, they move out. Or, when they have kids, they don't want their kids in an all-black school.

\section{Closing Down a Black Social Club}

Joe and Marlene's Club was a private black club established in the 1950s. By the 1990s, it was one of the last black-owned businesses in the neighborhood. Starting in the early 1990s, some newly arrived white gentrifiers complained about noise, loitering, fights, and drug dealing. Here are two examples of the many letters they wrote to the liquor license board:

I am a homeowner living adjacent to Joe and Marlene's Club. I am VERY disappointed that you have granted a liquor license to this business. The restrictions which accompany this license... will not suffice nor keep the patrons nor owners nor managers accountable... We, as residents, have a right to live in the neighborhood and NOT be affected by the unacceptable behavior of Joe and Marlene's patrons who are under the influence of intoxicants.

Another angry resident believes that the neighborhood is "improving" and views the social club as an impediment to further improvement:

I believe it would be beneficial to the [Upshaw] neighborhood if the social club's liquor license were not to be renewed. This area is improving more and more... Places like Joe and Marlene's Club are only a detriment to this progress.

Many of the complaining residents turned to UNA for assistance. UNA responded by negotiating a series of agreements with the club. The first agreements dealt with earlier closing times, increased security during the summer, and trash removal. When the complaining residents were not satisfied with the results of these changes, UNA and the social club negotiated further agreements, including raising the minimum age of patrons. This last move, however, proved financially costly to the club since it meant a reduction in patrons.

UNA initially served as a mediator between the club and complaining neighbors; however, they later took more direct actions to shut down the club: they discouraged renewing the club's liquor license and the club's proposal to change the venue to live jazz music. One longtime board member states that the city government, which includes the liquor license board, was more influenced by UNA's opinion than those expressed by club's proponents. When there were hearings at City Hall to discuss renewal of the club's liquor license, she felt that UNA had more of what Martin (2007) calls "external legitimacy" than the proponents: "The whole idea is the neighborhood (association's) concerns carry a lot of weight with city council... because they... are the official... representative (of the neighborhood)."

An interview with a past UNA board member suggests that the current board is disrespectful of the neighborhood's history and culture and is racially insensitive and exclusive. She says that before gentrification started, UNA was more respectful:

About eight years ago, there was a brief upset with... Joe and Marlene's Club. There's been a lot of upset about that place attracting people, the noise level, and the concern about gangs and just general neighborhood upset. I can understand it for people that live (close to the club), but I also thought that the response of the pretty much all-white neighborhood association was not respectful. The fact that that's been a club here for fifty to sixty years, predating all of us, and some slack has to be given... When I (was part of UNA) we seemed OK with Joe and Marlene's Club. In fact, we decided as a group that we would go there and have our social hour after our board meetings. At first, it was very awkward and then after it was very comfortable... [W] hen I talked to (current UNA board members) I was amazed at the lack of tolerance.

In the end, the club owners did not attempt to renew their liquor license and the club closed shortly after. To date, the building remains vacant and there are almost no remaining places for black residents to socialize in the neighborhood.

\section{Conclusion}

Scholars and activists clamor for the need for greater social 
inclusion of different types of minorities. Given the rise of neoliberalism, and therefore the rise in importance of local civic institutions to define and solve their own problems, it is important to examine the ways in which they do and do not promote social inclusion. This is especially important in U.S. cities since they have a growing number of racially mixed neighborhoods, some of which are in the process of gentrifying.

On the surface, UNA seems to answer the "social inclusion" call: its charter states that the interests of all neighborhood residents are important, regardless of their participation; and the UNA board members and their newsletter claim to embrace the ethos of diversity. In reality, however, this is a case of subtle social exclusion: UNA claim to embrace black residents, but engage in actions that exclude and hurt them, without ever mentioning race in their justification.

What is needed is more inclusion of black residents of all social classes in defining and advancing common neighborhood goals. This is a challenging task given limited racial trust and cross-cultural competence. The clearest way of establishing inter-racial cooperation and inclusion, or what Weisinger and Salipante (2005) call "racially bridging ties", is for UNA to collaborate with other neighborhood organizations that already have strong bonding ties with poor and black residents (see also Warren, 2001). Leaders of neighborhood organizations such as social service agencies and churches have a clear idea of the needs and interests of poor and black residents and have experience in how to interact with them (Cnaan, Boddie, \& McGrew, 2006).

The risk for UNA of establishing ties with other neighborhood organizations is that it may have to modify its agenda. However, if UNA becomes more receptive to the needs and interests of all its residents and finds ways to establish inter-organizational ties with those working with the poor and blacks, it could be a strong force in facilitating genuine social inclusion.

\section{REFERENCES}

Anderson, E. (1990). Streetwise. Chicago, IL: The University of Chicago Press.

Berrey, E. C. (2005). Divided over diversity. City \& Community, 4, 143170. doi:10.1111/j.1540-6040.2005.00109.x

Berry, J. M., Portney, K. E., \& Thomson, K. (1993). The rebirth of urban democracy. Washington DC: The Brookings Institution.

Bulick, B., Coletta, C., Jackson, C., Taylor, A., \& Wolff, S. (2003). Cultural development in creative communities. Monograph, Washington DC: Americans for the Arts.

Brown-Saracino, J. (2004). Social preservationists and the quest for authentic community. City \& Community, 3, 135-156. doi:10.1111/j.1535-6841.2004.00073.x

Cnaan, R. A., Boddie, S. C., \& McGrew, C. C. (2006). The other Philadelphia story. Philadelphia: University of Pennsylvania Press.

Crenshaw, E., \& St. John, C. (1989). The organizationally dependent community. Urban Affairs Quarterly, 24, 412-434. doi:10.1111/j.1535-6841.2004.00073.x

Curry-Stevens, A., Cross-Hemmer, A., Maher, N., \& Meier, J. (2011). The politics of data: Uncovering whiteness in conventional social policy and social work research. Sociology Mind, 1, 183-191. doi:10.4236/sm.2011.14024
DFID. (2005). Girls' education: Towards a better future for all. London: DFID.

Edwards, M. (1999). NGO performance-What breeds success? New evidence from South Asia. World Development, 27, 361-374. doi:10.1016/S0305-750X(98)00125-9

Florida, R. (2002). The rise of the creative class. New York: Basic Books.

Freiler, C. (2001). From experiences of exclusion to a vision of inclusion: What needs to change? Presentation for the CCSD/Laidlaw foundation conference on social inclusion. URL (last checked 2 January 2012). http://www.ccsd.ca/subsites/inclusion/bp/cf2.htm

Friedman, S. (2005). Neighborhood racial integration in US metropolitan areas, 1980-2000. Philadelphia, PA: The Population Association of America.

Hartigan, J. (1999). Racial situations. Princeton: Princeton University Press.

Islam, M. R. \& Sharmin, K. (2011). Social exclusion in non-government organizations' (NGOs') development activities in Bangladesh. Sociology Mind, 1, 36-44. doi:10.4236/sm.2011.12005

Kay, A. (2005). Social capital, the social economy and community development. Community Development Journal, 41, 160-173. doi:10.1093/cdj/bsi045

Kasinitz, P. (1988). The gentrification of "Boerum Hill”. Qualitative Sociology, 11, 163-182. doi:10.1007/BF00988953

Lee, B. A., \& Campbell, K. E. (1997). Common ground? Social Science Quarterly, 78, 922-936.

Maly, M. (2005). Beyond segregation. Philadelphia, PA: Temple University Press.

Martin, L. (2007). Fighting for control. Urban Affairs Review, 42, 603628. doi:10.1177/1078087406296604

Massey, D. S., \& Denton, N. A. (1993). American apartheid. Cambridge, MA: Harvard University Press.

Meyer, M., \& Hyde, C. (2004). Too much of a “good”thing? Nonprofit and Voluntary Sector Quarterly, 33, 77S-96S. doi:10.1177/0899764004265432

Myers, M. A. (1990). Black threat and incarceration in postbellum Georgia. Social Forces, 69, 373-393.

Nyden, P., Maly, M., \& Lukehart, J. (1997). The emergence of stable racially and ethnically diverse urban communities. Housing Policy Debate, 8, 491-534. doi:10.1080/10511482.1997.9521262

Pattillo, M. (2007). Black on the block. Chicago, IL: The University of Chicago Press.

Powell, J. L. (2011). Towards a sociology of trust. Sociology Mind, 1, 27-32. doi:10.4236/sm.2011.12003

Reed, A. J. (Ed.). (1999). Without justice for all. Boulder: Westview Press.

Saltman, J. (1991). Maintaining racially diverse neighborhoods. Urban Affairs Quarterly, 26, 416-441. doi:10.1177/004208169102600306

Schneider, J. A. (2006). Social capital and welfare reform. New York: Columbia University Press.

Smith, N. (1996). The new urban frontier. New York: Routledge.

St. John, C. \& Clark, F. (1984). Race and social class differences in the characteristics desired in residential neighborhoods. Social Science Quarterly, 65, 803-813.

Vargas, C. M. (2001). Community development and micro-enterprises: Fostering sustainable development. Sustainable Development, 8, 11-26. doi:10.1002/(SICI)1099-1719(200002)8:1<11::AID-SD119>3.0.CO; $\underline{2-7}$

Warren, M. A. (2001). Dry bones rattling. Princeton, NJ: Princeton University Press.

Weisinger, J. Y., \& Salipante, P. F. (2005). A grounded theory for building ethnically bridging social capital in voluntary organizations. Nonprofit and Voluntary Sector Quarterly, 34, 29-55. doi:10.1177/0899764004270069 